\title{
Prevalence of Connexin 26 Mutations in Patients from Jordan with Non Syndromic Hearing Loss
}

\author{
A.A. Mahasneh* and R. M. Battah \\ Department of Biotechnology and Genetic Engineering, Jordan University of Science and \\ Technology, P.O Box 3030, Irbid 22110, Jordan
}

KKEYWORDS Deafness; connexin 26; 35delG mutation; 167delT mutation

\begin{abstract}
Mutations in GJB2 gene are a major cause of autosomal recessive congenital hearing loss and the cause in some rare cases of the autosomal dominant form. The objectives of this study were to estimate the frequency of connexin $2635 \mathrm{delG}$ and $167 \mathrm{delT}$ mutations in congenital deaf Jordanian population and to estimate the frequency of carriers among normal Jordanian population. PCR was used to amplify two regions of the exon 2 of connexin 26 and PCR products were analyzed using $B s l$ I and Pst I analysis followed by gel electrophoresis. Homozygous 35delG was detected in fourteen out of $114(12.3 \%)$ of the familial group, while in the sporadic group there was one individual out of $38(2.6 \%)$. There were five individuals with a heterozygous mutations (35delG $/$ unknown), three of them were in the familial group $(2.6 \%)$ and two in the sporadic group $(5.3 \%)$. Among the normal group there was one carrier sample out of $95(1.1 \%)$. The 167 delT mutation was not detected in any of the deaf individuals, while it was detected in one individual from the normal group. The allele frequency for the 35delG mutation among the familial group was $13.6 \%$ and $5.3 \%$ for the sporadic group. The frequency of carriers among normal individuals was $1.1 \%$. For the $167 \mathrm{delT}$ mutation the allele frequency was zero for the familial and sporadic groups.
\end{abstract}

\section{INTRODUCTION}

Hearing is one of the five major senses that allow us to communicate with our surrounding environment. Hearing impairment is the most common sensory defect in human; affect one in 1000 children and whose prevalence increases with age (Rabionet et el. 2000 ; Liu et al. 2002). The understanding of genetics of hearing impairment advanced rapidly during the last decade of the $20^{\text {th }}$ century, also several essential genes, involved in the hearing mechanism, were cloned and localized to human genome. The mode of inheritance (dominant or recessive) of these genes is well known nowadays.

Many of those genes can cause other complications in addition to hearing impairment and are referred to as syndromic hearing loss and account for $30 \%$ of hearing loss, whereas those causing only hearing loss are referred to as nonsyndromic hearing loss and account for $70 \%$ of hearing loss (Rachel et al. 1999). Among hereditary nonsyndromic deafness, autosomal-

Corresponding Author: Dr. Amjad A. Mahasneh Department of Biotechnology and Genetic Engineering Jordan University of Science and Technology, P.O Box 3030, Irbid 22110, Jordan

Tel: $+962(79) 5588298$

Fax: +962 (2) 7095014

E-mail:amjada@just.edu.jo recessive heritance is predominant, accounting for about $80 \%$ of the cases (Morton 1991). Mutation in connexin26 gene account for nearly $50 \%$ of recessive nonsyndromic hearing loss (NSHL) in Caucasian populations. Up to now, more than 90 variants of connexin 26 gene have been reported (Tekin et al. 2003). Connexin26 gene, coded for gap junction protein 2 (GJP2), has two exons of about 2311 bp and mapped to chromosome thirteen (13q12), the second exon contains the most coding sequence of about 226 amino acid protein (Guilford et al. 1994; Petit et al. 2001). Gap junction proteins regulate the passage of inorganic ions and small metabolites, those of less than 1000 Dalton, between adjacent cells of most animal tissues. Thus coupling cells both electrically and metabolically. This type of communication is essential for organ homeostasis during development and adult life of multicellular organisms (Bruzzone 2001; Bruzzone et al. 2003). Connexin 26 gene is expressed in many tissues, but in the cochlea of the inner ear, this gene product plays an important role in the normal hearing by controlling the Potassiumrecycling pathway (Kikuchi et al. 2000).

GJP2 formed by cx 26 gene is used for returning potassium ions to the endolymph, which plays a key role in sensorneural hearing function (Kikuchi et al. 1995). Therefore any mutation in this gene will lead to disruption of the normal function of 
the inner ear, which leads to hearing impairment.

Many mutations have been detected in the coding region of cx 26 gene and most of them express nonfunctional gap junction proteins that cause hearing loss. World-wide $35 \mathrm{delG}$ mutation is the most common mutation of cx26 gene accounting for up to $85 \%$ of all GJP2 mutant alleles detected in Mediterranean populations (Estivill et al. 1998; Kelley et al. 1998; Lench et al. 1998; Denoyelle et al. 1997). Whereas, 167delT mutation is the second common one that cause hearing loss and was found to be the most common in Ashkenazi Jewish populations (Morell et al. 1998). Other mutations e.g. 235delC in Asian populations, R143W in Africa were also shown to cause hearing loss (Park et al. 2000).

The present study is directed toward the mutations caused along the cx26 gene using blood samples from deaf and normal Jordanian individuals. The objectives of the study were to estimate the frequency of cx26 35delG and 167delT mutations in deaf Jordanian population and to estimate the frequency of carriers of the these two mutations among normal Jordanian populations.

\section{MATERIALS AND METHODS}

Collection of Samples: Genomic DNA was extracted from blood samples obtained from 152 deaf patients and 95 healthy individuals. Deaf samples were collected from Al-Raja School for Deaf in Zarqa and Prince Ali Club for Deaf in Irbid. Healthy samples were collected from students at Jordan University of Science and Technology. All samples were collected during February 2003 and March 2004. The medical history of each patient was examined to exclude the environmental and infectious factors that cause deafness. In all samples taken deafness was congenital, prelingual and range from severe to profound. Non of the subjects showed signs or other findings associated with syndromes that involve permanent hearing impairment. A questionnaire covering demographic information as well as other information related to deafness was filled for each individual.

Prior to sample collection, written consent was obtained from patients or their parents in case of a minor and normal control individuals. The internal review committee on research using human subjects cleared the project after due deliberation.
DNA Extraction and PCR Analysis: Genomic DNA was extracted from whole blood using the "Wizard Genomic DNA Purification" Kit (Promega, USA) according to the manufacturer instructions. For $35 \mathrm{delG}$, a primer set was developed with a modified reverse primer for amplification of GJB2 sequence, based on the sequence entry for GJB2 in Gene Bank (accession no. M86849), so that a new restriction site for $B s l$ $\mathrm{I}$ is created only when the $35 \mathrm{delG}$ mutation is present. Bsl I recognizes the sequence 5'$\mathrm{CCN} 5 \downarrow \mathrm{N} 2 \mathrm{GG}-3$ '. The primer set consists of a wild-type forward primer 5'- GGT GAG GTT GTG TAA GAG TTG G (sense cDNA nucleotides 4869) and a modified reverse primer 5'- CTG GTG GAG TGT TTGTTC C*CA C (antisense cDNA nucleotides 233-254, modified at nucleotide 236). The $\mathrm{C}$ at nucleotide position 236, marked with an asterisk, replaces an A in the wild-type sequence and creates a $B s l$ I restriction site when the $35 \mathrm{delG}$ mutation is present. The PCR conditions were as follows: An initial denaturation at $94^{\circ} \mathrm{C}$ for five minutes, followed by 35 cycles of $94^{\circ} \mathrm{C}$ for one minute, $60^{\circ} \mathrm{C}$ for one minute, $72^{\circ} \mathrm{C}$ for one minute. A final extension was carried out at $72^{\circ} \mathrm{C}$ for 5 minutes.

For 167delT mutation, the following primers were used to amplify a $237 \mathrm{bp}$ fragment containing the mutation; Forward 5' GCT CAC CGT CCT CTT CAT TT 3' and Reverse 5' CTT CTT CTC ATG TCT CCG GTA 3'. The PCR conditions were as follows: An initial denaturation at $95^{\circ} \mathrm{C}$ for five minutes, followed by 32 cycles of $95^{\circ} \mathrm{C}$ for forty second, $65^{\circ} \mathrm{C}$ for thirty second, $72^{\circ} \mathrm{C}$ for one minute. The PCR machine used was iCycler from (BioRad, USA).

PCR reactions were performed in a $25 \mu$ final volume containing, $25 \mathrm{ng}$ of genomic DNA, 10 mM Tris- $\mathrm{HCl}, \mathrm{pH} 8.3,1.5 \mathrm{mM} \mathrm{MgCl} 2,50 \mathrm{mM} \mathrm{KCl}$, $0.1 \%$ Triton X-100, $200 \mu \mathrm{M}$ dNTPs, $10 \mathrm{pmol}$ of each primer and $0.6 \mathrm{U}$ Taq polymerase.

Restriction Enzymes Analysis: For detection of 35 delG mutation, PCR products were digested with $B s l$ I (New England Biolabs, USA) in a $20 \mu \mathrm{l}$ total reaction volume containing: $4.5 \mu \mathrm{l}$ of the PCR product, $2 \mu \mathrm{l}$ of $10 \mathrm{X}$ NB buffer, $0.5 \mu \mathrm{l}$ of the $B s l$ I enzyme $(10 \mathrm{U} / \mu \mathrm{l})$ and $13 \mu \mathrm{l}$ of nuclease free water. The reaction mixture was incubated in at $55^{\circ} \mathrm{C}$ for 16 hours.

For detection of 167 delT mutation, PCR precuts were digested with Pst I (Promega, USA) in a $20 \mu \mathrm{l}$ volume containing: $4 \mu \mathrm{l}$ of PCR product, $2 \mu \mathrm{l}$ of (10X) buffer $\mathrm{H}, 0.2 \mu \mathrm{l}$ acetylated bovine 
serum albumin, $1 \mu \mathrm{l}$ of Pst I $(10 \mathrm{U} / \mu \mathrm{l})$ and $12.8 \mu \mathrm{l}$ of nuclease free water. The mixture was then incubated at $37^{\circ} \mathrm{C}$ for 4 hours. Fifteen $\mu$ l of the digested PCR products were added to $3 \mu \mathrm{l}$ (6X) loading dye and loaded on $2 \%$ agarose gel and run at $80 \mathrm{~V}$ for three hours. The product sizes were determined by using $50 \mathrm{bp}$ ladder marker (Promega, USA).

For the 35delG mutation, the primer pair generated a PCR product of $207 \mathrm{bp}$. When the $35 \mathrm{delG}$ mutation is present (homozygous mutant), the $B s l$ I digested PCR product will give two fragments (181 bp and $26 \mathrm{bp}$ ). In the absence of the $35 \mathrm{delG}$ mutation (homozygous normal), the PCR product is not digested (one band at 207 bp). Heterozygous $35 \mathrm{delG}$ carriers will give three bands (207 bp, $181 \mathrm{bp}$ and $26 \mathrm{bp}$ ). For the 167delT mutation, the primer pair used generated a PCR product of $237 \mathrm{bp}$. Upon digestion with Pst I, homozygous normal will give three fragments (97 bp, 72 bp, 68 bp), homozygous mutant will give two fragments (165 bp and $72 \mathrm{bp}$ ) and heterozygous carriers will give four fragments (165 bp, 97 bp, 72 bp and 68 bp). Each sample was repeated at least twice to confirm the genotype. DNA representing positive controls for homozygous and heterozygous $35 \mathrm{delG}$ and 167 delT mutants was a kind gift from Dr. Ssa Francesca Gualandi, University of Ferrara, Italy.

\section{RESULTS}

A total of 152 blood samples from deaf individuals and 95 blood samples from healthy individuals were tested for the presence of mutations in the connexin26 gene using PCRrestriction enzyme analysis. Among deaf samples, there was $123(80.9 \%)$ males and $29(19.1 \%)$ females, the age was ranged from 7 to 52 years (mean 27 years). Whereas among healthy samples there was $67(70.5 \%)$ males and $28(29.5 \%)$ females, and the age ranged from 18-35 (mean 26 years). Based on medical history and pedigrees constructed based on the information given in the questionnaire, deaf individuals were divided into two groups; familial group, defined as individuals who have at least one deaf person in his family whether brother, sister, or parent. A second group called sporadic is defined as deaf with no affected family members. Normal group, defined as healthy individuals with no deaf individuals in his/her family or relatives. In the familial group, there were 114 deaf individuals $(75 \%)$ and in the sporadic group, there were 38 $(25 \%)$ deaf individuals.

The two mutations (35delG and 167delT) in exon two were detected using restriction enzyme analysis of the PCR products of the amplified sequences as shown in (Fig. 1 and Fig. 2), respectively. Homozygous $35 \mathrm{delG}$ was detected in fourteen out of 114 (12.3\%) of the familial group, while in the sporadic group there was one individual out of $38(2.6 \%)$. There were five individuals with a heterozygous compound mutations $\left(35 \mathrm{delG}^{+} /\right.$unknown), three of them were in the familial group $(2.6 \%)$ and two in the sporadic group $(5.3 \%)$. Among the normal group there was one carrier sample out of $95(1.1 \%)$, (Table 1).

The 167delT mutation was not detected in any of the deaf individuals, while it was detected

Table 1: Frequency of 35delG mutation among the studied Jordanian groups.

\begin{tabular}{lrcr}
\hline $\begin{array}{l}\text { Parameter/ } \\
\text { Group }\end{array}$ & $\begin{array}{c}\text { Homozygous } \\
\text { 35delG }\end{array}$ & $\begin{array}{c}\text { Compound } \\
\text { mutations } \\
\left(35 \text { delG }^{+} / 35 \text { delG }^{-}\right)\end{array}$ & $\begin{array}{c}\text { Frequency } \\
(\%)\end{array}$ \\
\hline Normal & $0 / 95$ & $1 / 95$ & $(1.1)$ \\
Familial & $14 / 114$ & $3 / 114$ & $(13.6)$ \\
Sporadic & $1 / 38$ & $2 / 38$ & $(5.3)$ \\
\hline
\end{tabular}

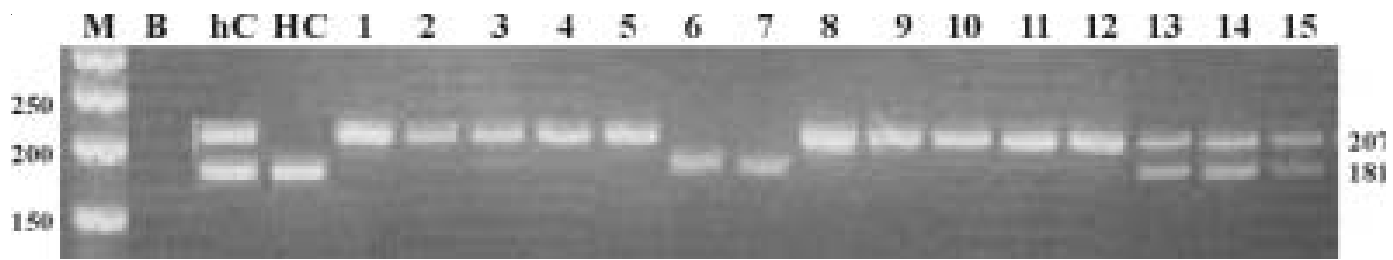

Fig. 1. 2\% agarose gel of exon 2 (35delG mutation) where PCR products were digested with $B s l$ I restriction endonuclease. Lane M: 50 bp DNA ladder, B: PCR Blank, Lane hC: heterozygous positive control, Lane HC: Homozygous positive control, Lanes (1-5): normal individuals, Lanes (6-7): deaf individuals with homozygous 35delG, Lanes (8-12) deaf individuals with no 35 delG mutation, Lanes (13-14): deaf individuals with heterozygous compound 35delG. Lane 15: normal individual carrier for 35 delG. 


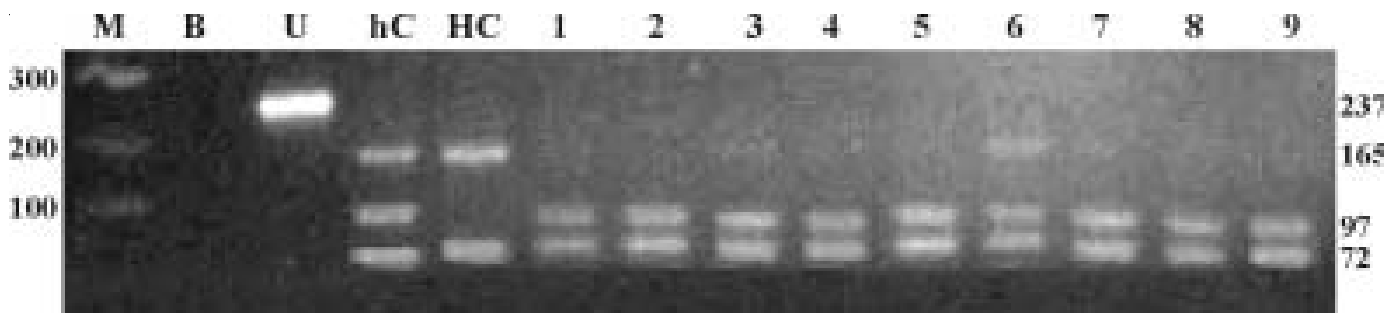

Fig. 2. 2\% agarose gel of exon 2 (167delT mutation) where PCR products were digested with Pst I restriction endonuclease. Lane M: 100 bp DNA ladder, B: PCR Blank, U: uncut PCR product, Lane hC: heterozygous positive control, Lane HC: Homozygous positive control, Lanes (1-5): normal individuals, Lane 6: heterozygous normal carrier individual Lane (7-9): deaf individuals with no $167 \mathrm{delT}$.

in one individual from the normal group as shown in (Fig.2, lane 6). By using Hardy Weinberg equation, the allele frequency of the $35 \mathrm{del} G$ mutation was calculated and found to be $13.6 \%$ for the familial group, and $5.3 \%$ for the sporadic group. The frequency of heterozygous carriers among normal individuals was $1.1 \%$. For the 167 delT mutation the allele frequency was zero for the familial and sporadic groups, but the frequency of heterozygous carriers among the normal group was $1.1 \%$ (Table 2).

Table 2: Frequency of 167 delT mutation among the studied Jordanian groups.

\begin{tabular}{|c|c|c|c|}
\hline $\begin{array}{l}\text { Parameter/ } \\
\text { Group }\end{array}$ & $\begin{array}{c}\text { Homozygous } \\
\text { 35delT }\end{array}$ & $\begin{array}{c}\text { Compound } \\
\text { mutations } \\
\left.\text { 35delT } T^{+} / 35 \text { del } T^{-}\right)\end{array}$ & $\begin{array}{c}\text { Frequency } \\
(\%) \\
\end{array}$ \\
\hline Normal & $0 / 95$ & $1 / 95$ & (1.1) \\
\hline Familial & $0 / 114$ & $0 / 114$ & - \\
\hline Sporadic & $0 / 38$ & $0 / 38$ & - \\
\hline
\end{tabular}

\section{DISCUSSION}

Until recently deafness was thought to be a highly complex problem due to extreme genetic heterogeneity. This complexity has now been greatly reduced since the description of a very common mutation in the most common form of genetic hearing loss. To date, four connexin genes have been demonstrated to underlie different forms of non-syndromic deafness. Mutations in Connexin 26 (GJB2) have been detected in many ethnic populations being tested in the world and are the most common cause of deafness in many populations (Kelsell et al. 1997). Connexin 31 (GJB3) is also expressed in the cochlea and is the cause of deafness in several Chinese pedigrees (Xia et al. 1998; Liu et al. 2000). Likewise, mutations in GJB6 (connexin 30) are the apparent common cause of deafness in Southern European populations (Grifa et al. 1999; del Castillo et al. 2000). Recently, GJAI (connexin 43) has been shown to cause non-syndromic recessive deafness and appears to be a common form of deafness in African Americans (Liu et al. 2001). It seems to be clear that specific mutations in a connexin gene or certain connexin genes play a predominant role in different ethnic populations.

In this study we investigated the association between two connexin 26 mutations and nonsyndromic recessive hearing loss among Jordanian population. Our results showed that the frequency of the $35 \mathrm{delG}$ mutation (13.6\%) among deaf Jordanians was similar to that for Palestinian population (14\%) and lower than that for Lebanese population (94\%) and to European Populations (60-80\%) (Shahin et al. 2002; Mustaapha et al. 2001; Wilcox et al. 2000). However, this mutation has not been detected in Omani, Japanese and Korean populations (Simsek et al. 2001; Abe et al. 2000; Park et al. 2000).

As the frequency of the $35 \mathrm{delG}$ mutation was small, testing 190 control chromosomes was necessary to assess the frequency of this mutation in the normal Jordanian population. Only 2 of these chromosomes $(1.1 \%)$ has the $35 \mathrm{delG}$ mutation, an indication of its relatively low frequency in this population, which is comparable to its prevalence in other populations such as Palestinians, Lebanese, Omani and Egyptian populations (Shahin et al. 2002; Mustaapha et al. 2001; Park et al. 2000; Van Laer et al. 2001). Therefore, its rare allelic frequency in normal Jordanian population and the subsequently rare 35 delG involvement in Jordanian non-syndromic recessive deafness $(13.6 \%)$ are not in favour of a common founder for the $35 \mathrm{delG}$ mutation. Indeed the absence of a common founder for this mutation could be 
expected since Jordan was always been a crossroad in the region and was occupied successively by various populations throughout history (Medlej-Hashim et al. 2002). However, high carrier frequencies of the GJB2 35delG mutation have been reported in many countries, with the highest carrier frequency so far being found in Greeks $(3.5 \%)$ and Italians (3.2\%) (Antoniadi et al. 1999; Gasparani et al. 2000).

It has been shown that $10-42 \%$ of patients with connexin 26 mutations have only one mutant allele (Liu et al. 2000). In our study, $2.6 \%$ of familial cases and $5.3 \%$ of the sporadic cases were found to carry single $35 \mathrm{delG}$ mutation.(i.e., they are heterozygotes). Our genotyping results showed the absence of 167delT mutation in both familial and sporadic groups. This is in agreement with what has been known about this mutation, mainly observed in Ashkenazi Jews (Morell et al. 1998). However, the carrier frequency for 167 delT mutation among normal Jordanian population was $1.1 \%$.

\section{ACKNOWLEDGMENT}

We are very thankful to all the participants and their families. This study is funded by the deanship of research at Jordan University of Science and Technology.

\section{REFERENCES}

Abe S, Usami S, Shinkawa H, Kelley PM, Kimberling WJ 2000. Prevalent connexin 26 gene (GJB2) mutations in Japanese. J Med Genet, 37: 41-43.

Antoniadi T, Rabionet R, Kroupis C, Aperis GA, Economides J, Petmesakis J et al. 1999. High prevalence in the Greek population of the $35 \mathrm{del} G$ mutation in the connexin 26 gene causing prelingual deafness. Clin Genet, 55:381-382

Bruzzone R 2001. Learning the language of cell-cell communication through connexin channels. Genome Biol, 2: 1-5.

Bruzzone R, Veronesi V, Gomes D, Bicego M, Duval N, Marlin S et al. 2003. Loss-of-function and residual channel activity of connexin26 mutations associated with non-syndromic deafness. FEBS Lett, 533:79-88.

del Castillo I, Villamar M, Moreno-Pelayo MA, Castillo FJ del, Alvarez A, Telleria D et al. 2002. A deletion involving the connexin 30 gene in nonsyndromic hearing impairment. $N$ Engl J Med, 346:243-249.

Denoyelle F, Weil D, Maw MA, Wilcox SA, Lench NJ, Allen- Powell DR et al. 1997. Prelingual deafness: high prevalence of a 30 delG mutation in the connexin 26 gene. Hum Mol Genet, 6: 2173-2177.

Estivill X, Fortina P, Surrey S, Rabionet R, Melchionda S, D'Agruma L et al. 1998. Connexin-26 mutations in sporadic and inherited sensorineural deafness.
Lancet, 351: 394-398.

Gasparani S, Rabionet R, Barbujani G, Melchionda S, Petersen P, Brondum-Nielson K et al. 2000. Genetic analysis consortium of GJB2 35delG. High carrier frequency of the $35 \mathrm{delG}$ deafness in European populations. Eur J Hum Genet, 8: 19-23

Grifa A, Wagner CA, D’Ambrosio L, Melchionda S, Bernardi F, Lopez-Bigas N et al. 1999. Mutations in GJB6 cause nonsyndromic autosomal dominant deafness at DFNA3 locus. Nat Genet, 23: 16-18.

Guilford P, Ayadi H, Blanchard S, Chaïb H, Le Paslier D, Weissenbach J, et al. 1994. A human gene responsible for neurosensory, non-syndromic recessive deafness is a candidate homologue of the mouse sh-1 gene. Hum Mol Genet, 3: 989-993.

Kelley PM, Harris DJ, Comer BC, Askew JW, Fowler T, Smith SD et al. 1998. Novel mutations in the connexin 26 gene (GJB2) that cause autosomal recessive (DFNB1) hearing loss. Am J Hum Genet, 62: 792-799.

Kelsell DP, Dunlop J, Stevens HP, Lench NJ, Liang JN, Parry G et al. 1997. Connexin 26 mutations in hereditary non-syndromic sensorineural deafness. Nature, 387: 80-83.

Kikuchi T, Kimura RS, Paul DL, Adams JC 1995. Gap junctions in the rat cochlea-immunohistochemical and ultrastructural analysis. Anat Embryol, 191: $101-118$.

Kikuchi T, Robert SK, David LP, Tomonori T, Joe CA 2000. Gap junction systems in the mammalian cochlea. Brain Research reviews, 32: 163-166.

Lench N, Houseman M, Newton V, Van Camp G, Mueller R 1998. Connexin-26 mutations in sporadic nonsyndromal sensorineural deafness. Lancet, 351: 415.

Liu XZ, Xia XJ, Adams J, Chen ZY, Welch KO, Tekin M et al. 2001. Mutations in GJA1 (connexin 43) are associated with non-syndromic autosomal recessive deafness. Hum Mol Genet, 25: 2945-2951.

Liu XZ, Xia XJ, Ke XM, Ouyang XM, Du LL, Liu YH, Angeli $S$ et al. 2002. The prevalence of connexin 26 ( GJB2) mutations in the Chinese population. Hum Genet, 111: 394-397.

Liu XZ, Xia XJ, Xu LR, Pandya A, Liang CY, Blanton $\mathrm{SH}$ et al. 2000. Mutations in connexin 31 underlie recessive as well as dominant non-syndromic hearing loss. Hum Mol Genet, 9: 63-67.

Medlej-Hashim M, Mustapha M, Choury E, Weil D, Parronaud J, Salem N et al. 2002. Non-syndromic recessive deafness in Jordan: mapping of a new locus to chromosome 9q34.3 and prevalence of DFNB1 mutations. Eur J Hum Genet, 10: 391-394

Morell RJ, Kim HJ, Hood LJ, Goforth L, Friderici K, Fisher R et al. 1998. Mutations in the connexin 26 gene (GJB2) among Ashkenazi Jews with nonsyndromic recessive deafness. $N$ Engl J Med, 211: 500-505.

Morton NE 1991. Genetic epidemiology of hearing impairment. Ann N Y Acad Sci, 630: 16-31.

Mustaapha M, Salem N, Delague V, Choury E, Ghassibeh M, Rai M et al. 2001. Autosomal recessive nonsyndromic hearing loss in the Lebanese population: Prevalence of the $30 \mathrm{delG}$ mutation and report of two novel mutations in the conenexin 26 (GJB2) gene. J Med Genet, 38:e36.

Park HJ, Hahn SH, Chun YM, Park K, Kim HN 2000. 
Connexin 26 mutations associated with nonsyndromic hearing loss. Laryngoscope, 110: 1535-1538.

Petit C, Jacqueline L, Hardelin JP 2001. Molecular Genetic of Hearing Loss. Annu Rev Genet, 35: 589646.

Rabionet R, Gasparini P, Estivill X 2000. Molecular genetics of hearing impairment due to mutations in gap junction genes encoding beta connexins. Hum Mutat, 16: 190-202.

Rachel AS, Lut VL, Guy VC, Richard JS 1999. Autosomal recessive nonsyndromic hearing loss. Am J Med Genet, 89: 123-129.

Shahin H, Walsh T, Sobe T, Lynch E, King MC, Avraham $\mathrm{KB}$ et al. 2002. Genetics of congential deafness in the Palestinian population: multiple connexin 26 alleles with shared origins in the Middle east. Hum Genet, 110: 284-289.

Simsek M, Al-Wardy N, Al-Khabory M 2001. A seminested PCR test for simultaneous detection of two common mutations (35delG and 167delT) in the connexin 26 gene. Mol Diagn, 6: 63-67.

Tekin M, Duman T, Bogoclu G, Incesulu A, Comak E, Ilhan I, Akar N 2003. Spectrum of GJB2 mutations in Turkey comprises both Caucasian and Oriental variants: roles of parental consanguinity and assortative mating. Hum Mutat, 5: 552-553.

Van Laer L, Coucke P, Muller RF, Cethoven G, Flothmann K, Prasad SD et al. 2001. A common founder for the 35 delG GJB2 gene mutation in connexin 26 hearing impairment. J Med Genet, 38: 515-518.

Wilcox SA, Osborn AH, Dahl HH 2000. Simple PCR test to detect the common 35 delG mutation in the connexin 26 gene. Mol Diagn, 5: 75-78.

Xia JH, Liu CY, Tang BS, Pan Q, Huang L, Dai HP et al. 1998. Mutations in the gene encoding gap junction protein beta-3 associated with autosomal dominant hearing impairment. Nat Genet, 20: 370-373. 